\title{
Irish Grassland Research - main achievements and advancements in the past 60 yrs and where to progress to next
}

\author{
M. O’Donovan ${ }^{1 \dagger}$, P. Dillon ${ }^{1}$, P. Conaghan ${ }^{2}$ and D. Hennessy ${ }^{1}$ \\ ${ }^{1}$ Teagasc, Animal and Grassland Research and Innovation Centre, Moorepark, Fermoy, Co. Cork, Ireland \\ ${ }^{2}$ Teagasc, Animal and Grassland Research and Innovation Centre, Oakpark, Co. Carlow, Ireland
}

Abstract

In the last 60 yr Irish grassland production has increased substantially in no small part due to high-quality fundamental grassland research. Increased production from grassland has arisen from improved understanding (research and practice) of soil and plant nutrition, plant physiology and variety improvement, while improved understanding of feed evaluation, ruminant nutrition, grazing management and silage technology has contributed to increased utilisation of grassland. Annual grass DM production varies from 12.7 to $15.0 \mathrm{t}$ DM/ha based on Department of Agriculture, Food and the Marine grass variety trials. More recent data from PastureBase Ireland indicate that average annual grass production (2020) on efficient dairy and dry stock farms is 13.5 and $10.0 t \mathrm{DM} / \mathrm{ha}$, respectively. Ireland is now one of the world leaders in grassland research, particularly in the area of grazing utilisation, the development and use of grassland databases, decision support systems and grass selection indices for grass varieties. Future pasture-based systems must extend beyond food production to deliver additional benefits to farmers, to consumers and the wider society. Future systems will require more robust grazing animals with healthier functional traits, more diverse swards supporting improved animal performance and require fewer fertiliser and chemical inputs, and will support more biodiversity and enhanced carbon storage.

Keywords

Animal production $\bullet$ grass breeding $\bullet$ grassland $\bullet$ grassland management $\bullet$ grazing

\section{Grassland science evolution}

Increased production from grassland in the last $60 \mathrm{yr}$ has arisen from improved understanding (research and practice) of soil and plant nutrition, plant physiology and variety improvement. At the same time, grassland utilisation has increased due to advances in feed evaluation, ruminant nutrition, grazing management and silage technology. Annual grass DM production varies from 12.7 to $15.0 \mathrm{t} \mathrm{DM} / \mathrm{ha}$ based on Department of Agriculture, Food and the Marine variety trials (DAFM, 2021). More recent data from PastureBase Ireland (PBI) indicate that average annual grass production (2020) on efficient dairy and dry stock farms is 13.5 and $10.0 \mathrm{t} \mathrm{DM} / \mathrm{ha}$, respectively (M. O'Leary, Teagasc, personal communication). In the early 1960s, national stocking rates were less than 0.8 livestock units (LU)/ha. The first experiments demonstrated that if some fertiliser nitrogen $(\mathrm{N})$ was applied for silage, it was possible to increase stocking rate to $2 \mathrm{LU} / \mathrm{ha}$. Early experimental design consisted of self-contained farmlets using rotational grazing. These became blueprint systems and were of great benefit to both advisors and farmers on how best to manage both livestock and grassland at farm level. By the mid-1970s, 2.47 LU/ha (or 1 LU/acre) or more became the norm on commercial grassland farms on dry soils. Over the next number of years, other factors influencing output per hectare were investigated including soil type/drainage, $\mathrm{N}$ fertiliser application rate, genetic merit of cows, concentrate supplementation and grass species/variety.

Research in the 1990s focused on the influence of grassland management on animal performance and this highlighted the importance of grass budgeting using decision support tools (DSTs) to aid grassland management. Additionally, the benefits of extending the grazing season in both spring and autumn, matching feed demand to grass supply and the importance of pasture-based animal genetics were identified. Forage legumes, particularly white clover (Trifolium repens L.), were highly regarded initially but their use declined mainly due to the low cost of $\mathrm{N}$ fertiliser (Gilliland et al., 2009) which 
was used in increasing amounts. White clover is assuming much more importance in the last decade due to increasing restrictions on current and future $\mathrm{N}$ fertiliser use as a result of policies and strategies introduced to reduce $\mathrm{N}$ loss, for example, EU Water Framework Directive (2000/60/EC), the Nitrates Directive (SI 378 2006), EU Farm to Fork Strategy 2020 and Government of Ireland Climate Action Plan. Recognition of the environmental implications of grassland production systems has increased, especially over the last two decades. This includes the need to reduce nutrient emissions from agriculture and improve water quality, but also the role of grassland in biodiversity protection, carbon sequestration and landscape quality.

\section{Key developments in grassland research}

The objective of grassland research is to study the factors which can influence and increase the output of sustainable animal production and to incorporate this knowledge into a complete integrated system. Some key developments over the last $60 \mathrm{yr}$ include:

- Research at Johnstown Castle quantified the effect of $\mathrm{N}$, phosphorus $(\mathrm{P})$, potassium $(\mathrm{K})$ and lime on grass production. The first soil survey in the 1970s mapped the soils of approximately half the country. This provided information on the productivity of soils and showed that soil drainage was a significant determinant in the level of production achieved. It was estimated that over 1 million ha of lowland required drainage which led to the development of both shallow and deep drainage systems.

- Much of the early work carried out at livestock research centres (Moorepark [Dillon et al., 2005], Grange [Drennan, 1999] and Athenry [Earle et al., 2017]) quantified the effect of stocking rate on milk, beef and lamb growth rates. The influence of grassland system (rotational vs. set stocking), soil type, drainage and $\mathrm{N}$ fertiliser use was investigated. The application of this knowledge led to the development of "blueprints" for animal production systems. In all those systems, the whole management programme for both animal and pasture was specified. These systems are now widely used on farm.

- A key challenge in the early years was the availability of and quality of winter feed. There was a great dependence on hay. In 1958, only 160,000 t of grass were conserved as silage, whereas by 1976 this had increased to 10 million t. The reasons for this expansion included the development of simple unroofed silos in conjunction with polythene covering, use of cold fermentation process, self-feeding systems and elimination of the risk associated with saving hay due to weather conditions. Key innovations included knowledge on when and how to conserve grass silage (Keating \& O'Kiely, 1997), improved machinery mechanisation, assessment of its feeding value and how it should be supplemented.

- Grassland management systems evolved placing greater emphasis on grazed grass rather than grass silage or concentrates in animal production. Key livestock production decisions like calving date (dairy, beef) and lambing date were targeted to maximise the use of grazed grass. This was only possible where grass-based animal genetics was used. Product quality also improved, and the benefits of grass-fed milk and meat were identified (e.g. Noci et al., 2005; O'Callaghan et al., 2016) giving Ireland a particular marketing advantage in production of "grass-fed" animal product.

- The Teagasc grass and clover breeding programme was initiated in 1960 to breed varieties suited to the Irish environment. Initially greater emphasis was placed on yield, but the emphasis changed over the years to give greater emphasis on seasonality of yield and quality. Over the period 1973-2013, it is estimated that annual grass DM yield increased by $0.52 \%$ under conservation and $0.35 \%$ under simulated grazing (McDonagh et al., 2016) in the Northern Irish evaluation lists. Over this period, there is no indication of any increase in herbage digestibility of the new varieties been released, but higher digestibility varieties have been released (McDonagh et al., 2016).

- A lot of research investment, infrastructure and resources were used over the years to develop and strengthen capacity in grassland science. This facilitated a greater understanding on the influence of grazing management on animal performance. The importance of pre-grazing herbage mass (e.g. Wims et al., 2010, 2014; Curran et al., 2010), pre- and post-grazing height (e.g. Stakelum \& Dillon, 2007; Ganche et al., 2015) as well as pasture allowance was identified (e.g. McEvoy et al., 2008; Curran et al., 2010). The use of markers to measure herbage intake helped greatly to understand the interaction between grazing management and animal nutritional requirements (Dillon, 1993). Knowledge gained from this work facilitated extending grazing season (spring and autumn) (e.g. Roche et al., 1996; Kennedy et al., 2005). Such advancements in grassland science have led to the development of decision-support "tools" which grass farmers now use (e.g. PBI) (Hanrahan et al., 2017).

- In the early 1980s, targets were established for milk and meat production. The milk production target was $6,820 \mathrm{~L} / \mathrm{cow}$ (3.5\% fat and $3.2 \%$ protein) and target live weight gain was $1,680 \mathrm{~kg} / \mathrm{ha}$ for beef production both at a stocking rate of $2.47 \mathrm{LU} / \mathrm{ha}$. In the current Teagasc Road Maps (Teagasc, 2020), dairy farmers nationally are achieving 5,484 L/cow at a stocking rate of $2.1 \mathrm{cows} / \mathrm{ha}$ (corrected for changes in milk composition), while current 
research performance is $5,800 \mathrm{~L} / \mathrm{cow}$ at a stocking rate of $2.70 \mathrm{cows} / \mathrm{ha}$. In suckler calf to beef systems, the current national average carcass weight output is $241 \mathrm{~kg} / \mathrm{ha}$ at a stocking rate of $1.6 \mathrm{LU} / \mathrm{ha}$, and the current research carcass weight output is $321 \mathrm{~kg} / \mathrm{ha}$ at a stocking rate of $1.6 \mathrm{LU} / \mathrm{ha}$ and $531 \mathrm{~kg} / \mathrm{ha}$ at a stocking rate of $2.6 \mathrm{LU} / \mathrm{ha}$.

\section{Grassland management developments}

The competitive advantage of Irish animal production systems is based on the efficient production and utilisation of grazed grass. Irish pasture has the potential to grow up to $15 \mathrm{tDM} / \mathrm{ha}$ per annum (O'Donovan et al., 2020), which is approximately $20 \%$ more than that produced in Western Europe (Peeters \& Kopec, 1996). Although grazing systems have specific challenges such as unstable feed supply and reduced individual animal intake and performance, the principle benefit of improved grazing management has been to optimise the quantity and nutritive value of the forage consumed by grazing animals. Notwithstanding the substantial benefits of pasture-based systems, engaging more farmers in pasture measurement in support of more rapid and improved pasture management continues to be problematic. One of the key challenges in the future will be to further increase animal production per hectare by improving pasture growth and grass quality, increasing $\mathrm{N}$ use efficiency (NUE) and reducing greenhouse gas (GHG) and ammonia emissions. Two important themes that the Teagasc grassland research programme is focused on in terms of grassland management to optimise production and utilisation are grassland measurement tools and grass growth modelling.

\section{Grassland decision support tools}

Efficient grazing management requires anticipation and flexibility, and can be greatly facilitated by the development of dynamic tools with the capability to simulate different scenarios based on regular measurement of farm grass supply. One of the major deficiencies in grassland management at farm level has been the lack of a measurement capability. O'Donovan et al. (2002) introduced the concept of grassland measurement using visual assessment to dairy farms in Ireland. The rising plate meter has been used successfully in Ireland and this technology has been improved through the incorporation of GPS and smartphone technology allowing it to be integrated with web-based grassland management tools (McSweeney et al., 2018; Murphy et al., 2021a, 2021b). The development and use of DSTs at farm level was not a new phenomenon. The key objective of most DSTs is to increase the information available to help the decision-making process at farm level. The advancement of the internet and in particular the proliferation of smart phones have created opportunities for the development and use of web-based DSTs that facilitated the collation of large quantities of data in a central data storage platform from different farms. The potential use of this information from a research perspective can be significant. Arguably, the most important step for the industry in the last $10 \mathrm{yr}$ in grassland in Ireland has been the introduction of PBI (www.pbi.ie). PastureBase Ireland is an internet-based grassland management DST. In operation since 2013, PBI offers farmers grassland decision support and stores a vast quantity of grassland data from dairy, beef and sheep farmers in a central national database. The inclusion of the data storage function dramatically increases its functionality as it enables the development of longer-term research-based solutions established from data collected over a longer time frame across a large range of farms. PastureBase Ireland also provides an automated mechanism to benchmark farms across periods and across a range of farms. Figure 1 shows the average daily grass growth rates in 2018, 2019 and 2020, and the average growth rate from 2013 to 2020 (inclusive) recorded on PBI.

\section{Grass growth modelling}

Another key area in terms of grassland management DSTs is grass growth modelling. Increasing the predictability of grass growth increases confidence in short-term feed budgeting. The development of the Moorepark St. Giles Grass Growth Model (MoSt GG model; Ruelle et al., 2018) has been a major advancement in terms of grass growth modelling on farm. For a grass growth prediction model to become a valuable grassland management DST, the model must be easily adaptable to a range of soil types and management conditions. To increase the likelihood of farm level use, few input data should be required. The model must respond to the main factors that influence grass growth including defoliation, $\mathrm{N}$ fertiliser application, $\mathrm{N}$ returned to soil from livestock faeces and urine and soil water content.

The MoSt model is a dynamic model capable of accurately simulating grass growth at field scale in a pasture-based system developed based on the adapted Jouven model (Jouven et al., 2006a, 2006b; Hurtado Uria, 2013) through the addition of soil, plant $\mathrm{N}$ and soil water sub-models. The MoSt model is now used to predict grass growth on grassland farms across Ireland. Information required to complete the predictions includes grassland measurements and fertiliser management which are recorded in PBI, as well as meteorological data provided by Met Éireann (www.met.ie). The MoSt model predicts the trend in grass growth (increase, decrease, static) weekly. This information is very valuable for short-term feed budgeting for farmers who operate grass-based feeding systems; the directional trend change in grass growth as well as the absolute value predicted are important, and the directional trend takes precedence. 


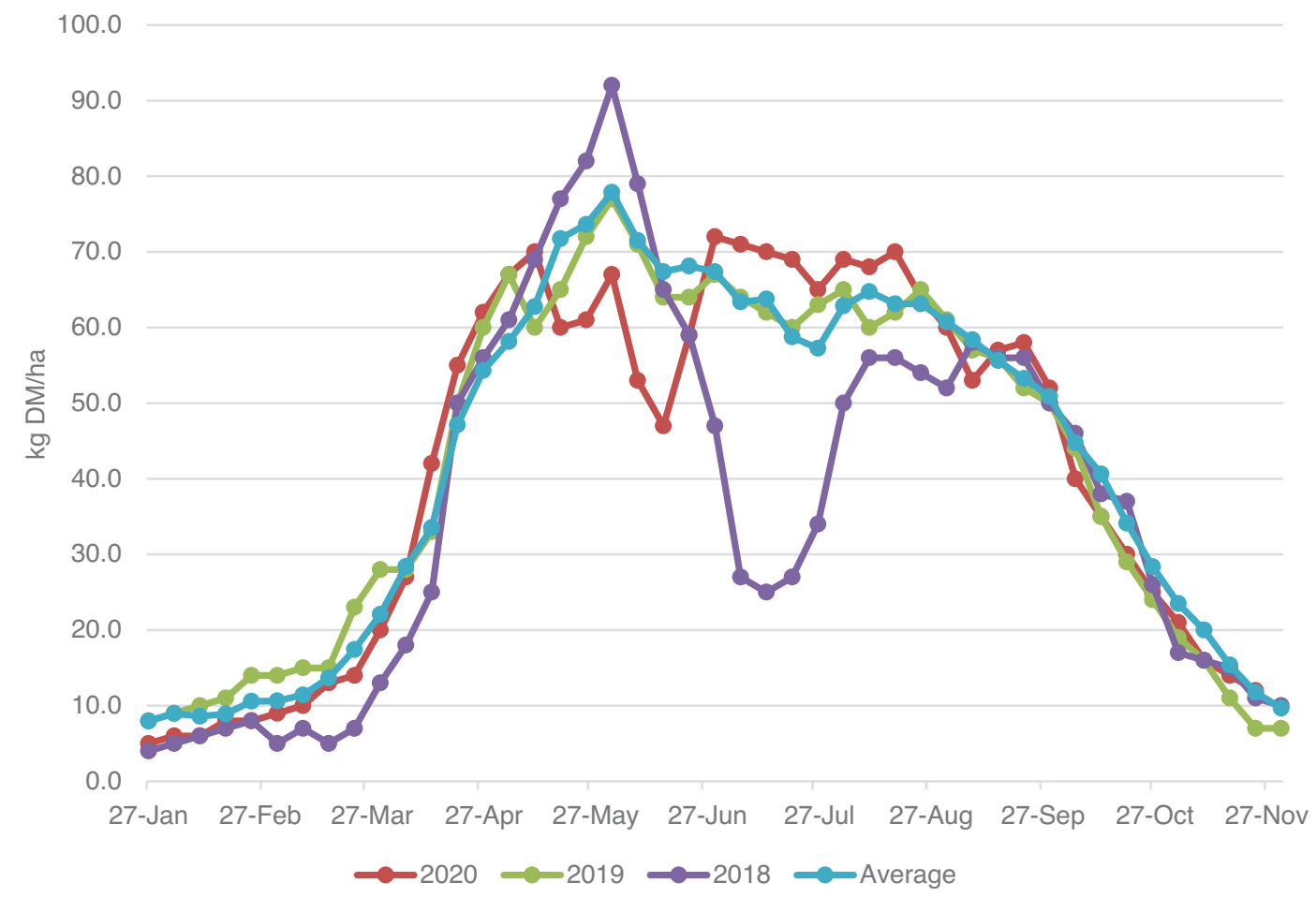

Figure 1. Daily grass growth rates (kg DM/ha) in 2018, 2019 and 2020 and the average growth rate from 2013 to 2020 (inclusive) recorded on PastureBase Ireland.

The model is currently (2021) predicting grass growth weekly on 50 commercial farms with the plan being to roll it out to all farms currently recording in PBI.

One of the main limitations of the MoSt GG model is that it does not consider pasture species other than perennial ryegrass or nutrients other than $\mathrm{N}$. While this increases the model usability by minimising the inputs required, it does limit the model functionality.

\section{Clover and other sward species}

White clover (Trifolium repens L.) is the most important sown legume species in grazed grassland in temperate regions including Ireland (e.g. Peyraud et al., 2009). The incorporation of white clover in grazing swards takes advantage of its capacity to fix atmospheric $\mathrm{N}$ and make it available for plant growth allowing the reduction in chemical $\mathrm{N}$ fertiliser (Egan et al., 2018; Enriquez Hidalgo et al., 2018). White clover has high digestibility and has a high energy value which is attributed to its low fibre concentration which reflects the absence of structural components such as stems and sheaths (Ayres et al., 1998). A particular advantage of white clover is the reduced rate of digestibility decline in the mid-season compared to perennial ryegrass (Ulyatt, 1970).
Increased production performance as a result of increasing the sward white clover proportion has been observed in dairy cows (Egan et al., 2018; McClearn et al., 2020), beef steers (Thomas et al., 1981) and sheep (Orr et al., 1990). The results depend on the proportion of sward white clover content. Egan et al. $(2017,2018)$ found that cows grazing a grass-white clover sward $(20 \%+$ clover content) had greater milk yield and milk solids yield than cows grazing a grass-only sward. Research in the areas of incorporating white clover into grassland swards to optimise their contribution and persistence is a significant focus of ongoing research efforts. At a time when white clover inclusion in grassland swards in Ireland is low, despite the well-documented benefits in terms of herbage and animal production and reduced $\mathrm{N}$ fertiliser requirement, the development of a Carbon Profit Index, similar to the Pasture Profit Index (PPI) (McEvoy et al., 2011; O'Donovan et al., 2016), will provide farmers with confidence in selecting the appropriate white clover varieties for their system.

Other sward species such as other legumes and herbs are being investigated to examine their role in reducing the use of chemical fertilisers and pesticides, improving soil quality and enhancing biodiversity, while maintaining or increasing herbage production and quality, and animal performance from grazed pasture. In the future, the development of selection 
indexes for other grassland species may also be important for the industry.

\section{Sward nutritive value}

Animal performance at grass is highly influenced by the voluntary grass DM intake (VDMI) of the animal and the organic matter digestibility (OMD) of the grass ingested (Stakelum \& Dillon, 2007). Accurate measurements of grass VDMI and OMD are difficult at grazing where pre-grazing herbage mass is a major factor affecting both the VDMI and OMD (Wims et al., 2010). Grass OMD is higher when grass is maintained at a low herbage mass, which should result in greater grass VDMI.

Organic matter digestibility remains the best single predictor of ruminant animal production from high forage diets. Grass quality, measured as OMD, is a key driver of animal performance in grazing systems and is associated with overall farm profit. Herbage mass has a substantial effect on the OMD of a sward (Stakelum \& Dillon, 2004; McEvoy et al., 2010). The chemical composition of a perennial ryegrass sward shows large variations from the top to the base of the sward, with decreasing OMD as depth increases in the sward (Delagarde et al., 2000). Perennial ryegrass varieties can vary in in vitro OMD due to differences in ploidy (Wims et al., 2013; Beecher et al., 2015) and heading date (O'Donovan \& Delaby, 2005), as well as sward structure (McEvoy et al., 2010).

There are opportunities to increase the productivity and efficiency of grass-based systems by strategically modifying the nutrient supply to the cow. To select the optimal strategy, quantitative knowledge of how the diet interacts with the ruminant, the nutrients it supplies and the metabolic requirements of the cow is crucial. Recent research using new feed chemistry demonstrates that the neutral detergent fibre fraction of immature pasture comprises a large potentially digestible pool that degrades rapidly in the rumen allowing for higher milk production performance to be achieved from grass-only diets (Dineen et al., 2021a). Autumn-grass was shown to contain a lower proportion of digestible material which degrades at a slower rate when compared with spring and summer grass (Dineen et al., 2021a; 2021b).

Harvesting and grazing management have to deal with the trade-off between grass quantity and quality. For silage conservation, grass should be cut at the beginning of the grass heading period to maximise net energy and protein harvested per hectare. At grazing, increased frequency of defoliation results in high-quality but a decrease in net herbage accumulation whereas infrequent defoliation leads to greater herbage production, but decreased grass feed value (Tunon, 2013). High biomass yield (kg DM/ha) at grazing will limit animal performance through digestive

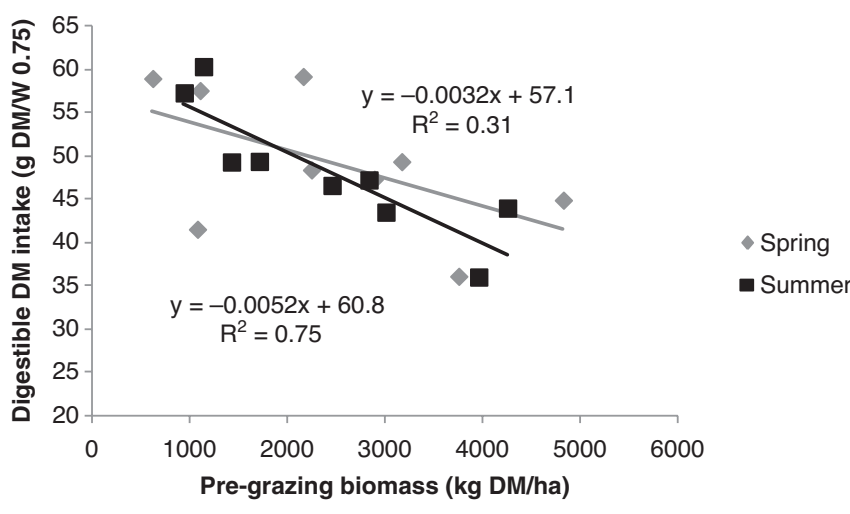

Figure 2. Effect of pre-grazing biomass on digestible DM intake measured in sheep (data from Beecher et al., 2017).

constraints (low intake of poorly digestible matter), but highquality swards (low pre-grazing yield) can also limit animal performance through behavioural constraints if the time required to graze the required grass quantity of grass is too great (Baumont et al., 2004). The effect of pre-grazing yield at grazing may also vary across the grazing season. Tunon (2013) found no effect of pre-grazing herbage mass up to $2,300 \mathrm{~kg} \mathrm{DM} / \mathrm{ha}(>4 \mathrm{~cm})$ on milk yield from April to July, but observed a reduction in milk fat plus protein yield compared to swards with pre-grazing herbage masses of 1,000 and $1,500 \mathrm{~kg} \mathrm{DM} / \mathrm{ha}$ from July to October. This agrees with Beecher et al. (2017) who observed no difference in OMD between swards with a pre-grazing mass $<1,500 \mathrm{~kg}$ $\mathrm{DM} / \mathrm{ha}$ and $>2,000 \mathrm{~kg} \mathrm{DM} / \mathrm{ha}$ in the May to July period, but in the July to October period observed that increasing pregrazing yield resulted in a significant decrease in OMD and digestible DM intake (Figure 2).

\section{Forage breeding advances}

The Teagasc forage breeding programme was established at Oakpark in 1960, although it was not until 1985 that the breeding of commercial varieties became the primary focus. The majority of resources in forage breeding programmes in northwest Europe are committed to the improvement of perennial ryegrass given it is the main forage species sown in this region. White clover and red clover, the principal legumes for temperate grassland, are subject to significantly less breeding effort. In Europe, varieties cannot be sold without first undergoing and passing a National List or Recommended List (RL) evaluation system. The first Irish $\mathrm{RL}$ was published in 1976. The RL is highly influential with almost all seed sales in Ireland today consisting of RL varieties (Grogan \& Gilliland, 2011). Given their importance, breeders' trials tend to mimic 
the $\mathrm{RL}$ trials and are not motivated to select for traits not measured in the RL trials (Stewart \& Hayes, 2011).

Traditionally, the core target traits for improvement have been production and adaptation traits such as forage yield, persistence and disease resistance reflecting the traits measured in RL trials. The genetic gain in annual DM yield of perennial ryegrass and white clover has been estimated at 4\%-6\% per decade (Brummer \& Casler, 2014; Gilliland et al., 2021). This is modest in comparison with the $10 \%-15 \%$ per decade genetic improvement in cereal seed yield. The lag in the genetic gain of forage species is due to several biological factors and limited seed industry investment as forages are minor species in terms of global seed sales (Annicchiarico et al., 2016).

Genetic improvement for nutritional value traits in perennial ryegrass has been modest with DM digestibility (DMD) increasing by $5-10 \mathrm{~g} / \mathrm{kg}$ DM $(0.5 \%-1 \%)$ per decade (Gilliland et al., 2020). This may be attributed to limited breeding effort, as nutritional value is a relatively new addition to the $\mathrm{RL}$. Grass $\mathrm{DMD}$ value was first added to the Ireland $\mathrm{RL}$ in 2009. Nutritional value is now a core trait for improvement in most grass breeding programmes but given that it typically takes 15-20 yr to develop, test and release a new variety, the effects of this increased breeding effort is only starting to be realised in new varieties.

\section{Breeding methods}

While animal production is not directly measured in $R L$ trials, animals are often used to apply a grazing pressure in evaluation trials, particularly for legumes. This facilitates selection for grazing resilience (Gilliland et al., 2021). Taking this a step further, Teagasc Moorepark began measuring the residual grazed height of $\mathrm{RL}$ trials after grazing with dairy cows. From this, a new grazing utilisation trait was created (Tubritt et al., 2020) which was first added to the Ireland RL in 2021. The Teagasc breeding programme began measuring the residual post-grazing height of perennial ryegrass families in 2018.

Grass and clover breeding systems are based on recurrent restricted phenotypic selection and among-and-within-family selection (Conaghan \& Casler, 2011). Selection is practiced on spaced plants and sward plots. The use of sward plots is less efficient than spaced plants as the selection intensity is lower and breeding cycle longer. Sward plots are necessary as not all traits, particularly forage yield, can be improved using spaced plants (Conaghan \& Casler, 2011).

\section{Grass variety selection indices}

Perennial ryegrass variety economic selection indices such as the PPI in Ireland and the Forage Value Index (FVI) in New Zealand and Australia have been developed to aid variety selection decisions within the grassland industry. These indices utilise data from evaluation trials (O'Donovan et al., 2016; Chapman et al., 2017) expressing superior variety performance based on a total merit index (i.e. expressed as an increase in net profit per year). These indices increase the value of the information supplied to the end user, creating a communication tool expressed in a language (i.e. profit) that users more readily relate to. The relative difference between varieties for all traits is expressed in economic terms indicating the additional profit generated by one variety against another (O'Donovan et al., 2016). Farmers can use the PPI to select varieties based on their total economic merit (sum of all traits) or by focusing on individual traits deemed to be of greater importance (McEvoy et al., 2011).

Grazing efficiency of perennial ryegrass varieties influences the amount of herbage which can be utilised (Byrne et al., 2017). Swards that are consistently grazed to low post-grazing sward heights $(<4 \mathrm{~cm})$ support the highest utilisation levels (McCarthy et al., 2013). Hanrahan et al. (2018) reported that utilisation was one of the single largest (controllable) variables affecting profitability of ruminant systems with each additional tonne of DM utilised increasing profitability of dairy farms by $€ 173 /$ ha. Utilisation is a function of herbage production and harvesting by the animal which can be influenced by perennial ryegrass varieties. Herbage production is already captured in the PPI, but relative differences between varieties for grazing efficiency are not included as yet. Byrne et al. (2018) reported a $0.3-\mathrm{cm}$ difference between diploids and tetraploids in achieved post-grazing sward height with the increased digestibility and lower tiller density of these varieties, compared to diploids, responsible for the grazing difference. Varietal grazing efficiency evaluation protocols have been developed by Tubritt et al. (2020) which, in agreement with Byrne et al. (2018), have found important differences between varieties in their ability to be grazed by cattle. The results from these protocols have provided the data necessary to develop a grazing efficiency sub-index within the PPI.

\section{Future of grass breeding}

Today, forage breeders are challenged by the difficulty of addressing contrasting demands by farmers (higher animal production potential) and society (reduced environmental and climatic footprint).

Genetic variation for the trait of interest is vital for breeding gain but suitable variation for new traits may not be available in the predominate species of today. This variation may be found in novel species that offer functional diversity in grassland (e.g. Caucasian clover [Trifolium ambiguum], birdsfoot trefoil [Lotus corniculatus], lotus [Lotus pedunculatus], sainfoin [Onobrychis viciifolia], chicory [Cichorium intybus], plantain [Plantago lanceolata] and interspecific hybrids). Increasing the number of species bred reduces the breeding effort per species although the magnitude of such depends on the breeding 
methodology and trait selection. The Teagasc forage breeding programme presently conducts four breeding programmes in parallel: diploid and tetraploid perennial ryegrass, white clover and red clover.

Gilliland et al. (2021) identified 33 potential traits for selection in perennial ryegrass. The authors noted that instances of breeding for novel traits are isolated. Breeders are conscious that, for a given level of genotypes evaluated, the higher the number of selected traits, the smaller the genetic gain for each trait. As it is necessary to assess all important traits in each generation of selection in order to produce improved varieties without major faults (Wilkins \& Humphreys, 2003), selecting for more traits has an exponential effect on the breeding effort (Annicchiarico et al., 2016). Potential novel traits include protein and mineral content, fatty acid profile, anthelmintic and bloat safe properties, $\mathrm{N}$-fixation rate, root architecture, $\mathrm{N}$ and $\mathrm{P}$ use efficiency, methane emissions and mixture compatibility, to name but a few. Selecting for novel traits can offer varieties a unique marketing advantage but only if farmer appreciation is high. This can be difficult to achieve if the trait is not measured on the $\mathrm{RL}$, the variety ranks low in other traits on the RL and the main market for seed is from intensive farmers who consider production traits foremost. Changes to the RL, including a specialist variety and trait category, would encourage breeders to select for novel traits.

Despite considerable investment worldwide in molecular breeding technologies over the past two decades, markers have contributed little to the development of any forage varieties to date (Annicchiarico et al., 2016). The development of genotyping-by-sequencing procedures at a very low cost per data point may change that. Genomic selection (GS), based on the use of genome-wide markers to develop prediction equations for traits, enables selection of plants at an early developmental stage and replaces the need to phenotype the target trait for one or more selection cycles. Genomic selection may accelerate genetic gain by (i) shortening the breeding cycle, (ii) increasing the number of selection cycles per unit time, (iii) increasing selection intensity and (iv) utilising within-family additive genetic variation (Annicchiarico et al., 2016). Genomic selection is especially attractive for improving traits that require labour-intensive, expensive and multi-year evaluations. The application of GS may allow breeders to select for more traits while maintaining comparable selection intensity and genetic gain for each trait. The successful application of GS requires high-quality phenotypic data on a reasonably sized population to build a high-confidence, robust model. Characterising plant phenotypes is a major bottleneck in the process. High-throughput phenotyping using advances in machinery, optical sensors and machine learning is necessary to fully exploit GS. Genomic selection does not eliminate phenotyping. Phenotyping must continue on an annual basis to allow frequent updates and improvements to the GS model (Brummer \& Casler, 2014). Thus, GS will increase the total cost of the breeding programme but this should be recouped in greater genetic gain. While theoretical models indicate a two- to three-fold increase in genetic gain with GS (Pembleton et al., 2018), they are largely untested in forages for key traits such as DM yield and nutritional value (Arojju et al., 2020; Faville et al., 2020). Critical parameters for GS in forages are gradually being elucidated.

\section{Future grassland research direction}

Ruminant production systems in Ireland are and will continue to be pasture-based and so the focus of research must continue to focus on evaluation under grazing.

(1) The movement of grassland research onto grassland farms aided by PBI allows a greater understanding of the performance of grass and white clover varieties in an on-farm scenario including variation in management, stocking rate, soil type and fertility, and grazing pressure as well as the interaction with grazing, persistence, grazing season length and multiple years data. One of the main limitations of much grassland research is the lack of long-term datasets; the key to understanding grass variety or clover persistence is multi year's data.

(2) The use of grass growth modelling to examine and understand the effects of climate limitations, soil type, climatic variables and their impacts in the longer term, as well as effects of soil fertility and sward species composition on grass growth.

(3) The use of the MoSt model to better manage $\mathrm{N}$ use and requirements across the grass growing season will be key in promoting fertiliser management change for the grassland industry. The use of predictive real-time data for $\mathrm{N}$ management and a move away from date-bound decisions to more informed decision making based on real-time data is a key prerequisite of better $\mathrm{N}$ management for the industry.

(4) Future developments with the MoSt will include the incorporation of other pasture species (especially white clover) and other nutrients to increase the model's functionality and usefulness.

(5) The continued use of the grazing system experimental approach with the application of decision/management rules. While the use of component research is useful, it does not give the entire complexity of the treatment within the system. The use of multiple sites for research is important.

(6) In grassland nutrition, strategies including improved grassland management, optimisation of concentrate supplementation and selection of superior plant genetics are still major avenues of research focus. Ruminants consuming grass-based diets exhibit a large dependence on microbial amino acids to support metabolisable amino 
acid supply; how and when (season) this can be balanced is an area that requires further research to increase our understanding and knowledge.

(7) The creation of high-quality, high tannin, low methane emission swards is now a key aspect of grassland research. Perennial ryegrass is invariably low in tannin content, so the pursuit of high tannin species can be complimentary to the focus of reducing methane emissions of grazing ruminants.

(8) The use of more grazing in plant species evaluations; there is currently limited work completed. For example, in recent years, the benefits of multispecies swards under cutting/mowing have been documented but little to no grazing evaluation has taken place. There is a requirement for the grassland science, plant breeding and grass evaluation to be more proactive in moving to more intensive evaluations under grazing.

(9) Grass breeding needs to focus on more grazing traits in the future, specifically grazing utilisation, mid-season quality and DM production over time rather than sward ground score.

(10) Understanding the factors affecting establishment and persistence of white clover in grasslands is of key importance in developing protocols for over-sowing and reseeding to deliver productive persistent white clover swards that allow chemical $\mathrm{N}$ fertiliser use to be reduced.

(11) The role of multispecies swards in our pasture-based systems must be evaluated and defined. Suitable species and combinations of species need to be evaluated. The research must focus on the added value aspect of specific species to the overall DM production, persistence, $\mathrm{N}$ fixation, canopy morphology and sward quality of the swards. Added benefits these may bring in terms of environmental benefits (e.g. reduced $\mathrm{N}$ loss, increase soil C content) to grazed pasture must be quantified.

(12) A deeper understanding of the role of grasslands in delivering ecosystem services and addressing environmental challenges such as improvements in water quality, above and below ground biodiversity, and reductions in GHG emissions.

(13) The uptake of DSTs in grassland continues to be slow; however, their role in the improvement of grassland production and utilisation can be immense. The role of peer-to-peer learning and the creation of grasslandfocused discussion groups will assist this process.

\section{References}

Annicchiarico, P., Boller, B., Brummer, E.C. and Reheul, D. 2016. Improving the focus of forage breeding research. In: "Breeding in a World of Scarcity: Proceedings of the 2015 Meeting of the
Section Forage Crops and Amenity Grasses of Eucarpia, Ghent, Belgium, 13-17 September 2015" (eds. I. Roldán-Ruiz, J. Baert and D. Reheul), Springer International Publishing, Switzerland, pages 251-268.

Arojju, S.K., Cao, M., Jahufer, M.Z.Z., Barrett, B.A. and Faville, M.J. 2020. Genomic predictive ability for foliar nutritive traits in perennial ryegrass. G3 Genes Genomes Genetics 10: 695-708.

Ayres, J.F., Nandra, K.S. and Turner, A.D. 1998. A study of the nutritive value of white clover in relation to different stages of phonological maturity in the primary growth in spring. Grass and Forage Science 53: 250-259.

Baumont, R., Cohen-Salmon, D., Prache, S. and Sauvant, D. 2004. A mechanistic model of intake and grazing behaviour in sheep integrating sward architecture and animal decisions. Animal Feed Science and Technology 112: 5-28.

Beecher, M., Hennessy, D., Boland, T.M., McEvoy, M., O'Donovan, M. and Lewis, E. 2015. The variation in morphology of perennial ryegrass cultivars throughout the grazing season and effects on organic matter digestibility. Grass and Forage Science 70: 19-29.

Beecher, M., Baumont, R., O'Donovan, M., Boland, T.M., Aufrère, J., Fleming, C., Galvin, N. and Lewis, E. 2017. Effects of harvesting perennial ryegrass at different levels of herbage mass on voluntary intake and in vivo digestibility in sheep. Grass and Forage Science 73: 553-561.

Brummer, E.C. and Caler, M.D. 2014. Cool-season forages. In: "Yield Gains in Major U.S. Field Crops", CSSA Special Publication 33 (eds. S. Smith, B. Diers, J. Specht and B. Carver), ASA, CSSA, and SSSA, Madison, WI, pages 33-51.

Byrne, N., Gilliland, T.J., McHugh, N., Delaby, L., Geoghegan, A. and O'Donovan, M. 2017. Establishing phenotypic performance of grass varieties on Irish grassland farms. The Journal of Agricultural Science 155: 1633-1645.

Byrne, N., Gilliland, T.J., Delaby, L., Cummins, D. and O'Donovan, M. 2018. Understanding factors associated with the grazing efficiency of perennial ryegrass varieties. European Journal of Agronomy 101: 101-108.

Chapman, D.F., Bryant, J.R., Olayemi, M.E., Edwards, G.R., Thorrold, B.S., McMillan, W.H., Kerr, G.A., Judson, G., Cookson, T., Moorhead, A. and Norriss, M. 2017. An economically based evaluation index for perennial and short-term ryegrasses in New Zealand dairy farm systems. Grass and Forage Science 72: 1-21.

Conaghan, P. and Casler, M.D. 2011. A theoretical and practical analysis of the optimum breeding system for perennial ryegrass. Irish Journal of Agricultural and Food Research 50: 47-63.

Curran, J., Delaby, L., Kennedy, E., Murphy, J.P., Boland, T.M. and O'Donovan, M. 2010. Sward characteristics, grass dry matter intake and milk production performance are affected by pregrazing herbage mass and pasture allowance. Livestock Science 127: $144-154$.

DAFM. 2021. Department of Agriculture Food and the Marine Grass and White Clover Recommended List Varieties for Ireland 2021. Available online: https://www.gov.ie/en/publication/8dbf3-grass- 
and-white-clover-recommended-list-varieties-for-ireland-2021/ [Accessed 20 May 2021].

Delagarde, R., Peyraud, J.L., Delaby, L. and Faverdin, P. 2000. Vertical distribution of biomass, chemical composition and pepsincellulase digestibility in a perennial ryegrass sward: Interaction with month of year, regrowth age and time of day. Animal Feed Science and Technology 84: 49-68.

Dillon, P. 1993. The use of n-alkanes as markers to determine herbage intake, botanical composition of available or consumed herbage and in studies of digesta kinetics with dairy cows. PhD Thesis, National University of Ireland, Dublin, Ireland, page 272.

Dillon, P., Roche, J.R., Shallo, L. and Horan, B. 2005. Optimising financial return from grazing in temperate pastures. In: "Utilisation of grazed grass in temperate animal systems". Proceedings of a satellite workshop of the XXth international grassland congress, Cork, Ireland, 9th Editon (ed. J.J. murphy), Wageningen Academic Publishers, The Netherlands, pages 131-148.

Dineen, M., McCarthy, B., Ross, D., Ortega, A., Dillon, P. and Van Amburgh, M.E. 2021a. Characterization of the nutritive value of perennial ryegrass (Lolium perenne L.) dominated pastures using updated chemical methods with application for the Cornell Net Carbohydrate and Protein System. Animal Feed Science and Technology 272: 114752.

Dineen, M., McCarthy, B., Dillon, P., Mattews, C., Ross, D. and Van Amburgh, M.E. 2021b. Microbial composition and omasal flows of bacterial, protozoal, and nonmicrobial amino acids in lactating dairy cows fed fresh perennial ryegrass (Lolium perenne L.) not supplemented or supplemented with rolled barley. Journal of Dairy Science 104: 4192-4205.

Drennan, M.J. 1999. Development of a competitive suckler beef production system. Teagasc, Grange Research Centre, Dunsany, Co Meath, Beef Production Series No. 18. ISBN 1841700878.

Earle, E., McHugh, N., Boland, T.M. and Creighton, P. 2017. Effect of ewe prolificacy potential and stocking rate on ewe and lamb performance in a grass-based lamb production system. Journal of Animal Science 95: 154-164.

Egan, M., Lynch, M.B. and Hennessy, D. 2017. Including white clover in nitrogen fertilized perennial ryegrass swards: effects on dry matter intake and milk production of spring calving dairy cows. Journal of Agricultural Science 155: 657-668.

Egan, M., Galvin, N. and Hennessy, D. 2018. Incorporating white clover (Trifolium repens L.) into perennial ryegrass (Lolium perenne L.) swards receiving varying levels of nitrogen fertiliser: effects on milk and herbage production. Journal of Dairy Science 101: 3412-3427.

Enriquez-Hidalgo, D., Gilliland, T.J., Egan, M. and Hennessy, D. 2018. Production and quality benefits of white clover inclusion into ryegrass swards at different nitrogen fertilizer rates. Journal of Agricultural Science 156: 378-386.

Faville, M., Cao, M., Schmidt, J., Ryan, D., Ganesh, S., Jahufer, M., Hong, S., George, R. and Barrett, B. 2020. Divergent genomic selection for herbage accumulation and days-to-heading in perennial ryegrass. Agronomy 10: 340.
Ganche, E., O'Donovan, M., Delaby, L., Boland, T.M. and Kennedy, E. 2015. Does post-grazing sward height influence sward characteristics, seasonal herbage dry-matter production and herbage quality? Grass and Forage Science 70: 130-143.

Gilliland, T.J., McGilloway, D. and Conaghan, P. 2009. Influence of testing procedure on evaluation of white clover (Trifolium repens L.). Irish Journal of Agricultural and Food Research 48: 227-242.

Gilliland, T.J., Annicchiarico, P., Julier, B. and Ghesquière, M. 2020. A proposal for enhanced EU herbage VCU and DUS testing procedures. Grass and Forage Science 75: 227-241.

Gilliland, T.J., Ball, T. and Hennessy, D. 2021. Opportunities and challenges for breeding perennial ryegrass cultivars with improved livestock production potential. Irish Journal of Agricultural and Food Research. DOI: 10.15212/IJAFR-2020-0111.

Grogan, D. and Gilliland, T.J. 2011. A review of perennial ryegrass variety evaluation in Ireland. Irish Journal of Agricultural and Food Research 50: 65-81.

Hanrahan, L., Geoghegan, A., O' Donovan, M., Griffith, V., Wallace, M. and Shalloo, L. 2017. PastureBase Ireland: a grassland decision support system and national database. Computers and Electronics in Agriculture 136: 193-201.

Hanrahan, L., McHugh, N., Hennessy, T., Moran, B., Kearney, R., Wallace, M. and Shalloo, L. 2018. Factors associated with profitability in pasture-based systems of milk production. Journal of Dairy Science 101: 5474-5485.

Hurtado-Uria, C. 2013. Evaluation, adaptation and validation of a model to predict grass growth in Ireland. PhD Thesis, Department of Mathematics, Cork Institute of Technology, Bishopstown, Cork, Ireland.

Jouven, M., Carrere, P. and Baumont, R. 2006a. Model predicting dynamics of biomass, structure and digestibility of herbage in managed permanent pastures. 1. Model description. Grass and Forage Science 61: 112-124.

Jouven, M., Carrère, P. and R. Baumont, R. 2006b. Model predicting dynamics of biomass, structure and digestibility of herbage in managed permanent pastures. 2. Model evaluation. Grass and Forage Science 61: 125-133.

Keating, T. and O'Kiely, P. 1997. Irish farm silages 1993-1996. Proceedings of the Agricultural Research Forum, 3-4 April, Teagasc, pages 123-124.

Kennedy, E., O’Donovan, M., Murphy, J.-P., Delaby, L. and O'Mara, F. 2005. Effects of grass pasture and concentrate-based feeding systems for spring-calving dairy cows in early spring on performance during lactation. Grass and Forage Science 60: 310-318.

McCarthy, B., Pierce, K.M., Delaby, L., Brennan, A., Fleming, C. and Horan, B. 2013. The effect of stocking rate and calving date on grass production, utilization and nutritive value of the sward during the grazing season. Grass and Forage Science 68: 364-377.

McClearn, B., Gilliland, T.J., Guy, C., Dineen, M., Coughlan, F. and McCarthy, B. 2020. The effect of perennial ryegrass ploidy and white clover inclusion on milk production of dairy cows. Animal Production Science 60: 143-147. 
McDonagh, J., O'Donovan, M., McEvoy, M. and Gilliland, T.J. 2016. Genetic gain in perennial ryegrass (Lolium perenne) varieties 1973 to 2013. Euphytica 212: 187-199.

McEvoy, M., Kennedy, E., Murphy, J.P., Boland, T.M., Delaby, L. and O'Donovan, M. 2008. The effect of herbage allowance and concentrate supplementation on milk production performance and dry matter intake of spring-calving dairy cows in early lactation. Journal of Dairy Science 91: 1258-1269.

McEvoy, M., Delaby, L., Murphy, J.P., Boland, T.M. and O'Donovan, M. 2010. Effect of herbage mass and allowance on sward characteristics, milk production, intake and rumen volatile fatty acid concentration. Grass and Forage Science 65: 335-347.

McEvoy, M., O'Donovan, M. and Shalloo, L. 2011. Development and application of an economic ranking index for perennial ryegrass cultivars. Journal of Dairy Science 94: 1627-1639.

McSweeney, D., Coughlan, N.E., Cuthbert, R.N. and Halton, P. 2018. Grasshopper: micro-sonic sensortechnology enables enhanced height measuremen by a rising plate meter. Proceedings of the 27th Genberal Meeting of the European Grassland Federation 'Sustainable meat and milk production from grasslands', 17-21 June 2018, Cork, Ireland, Grassland Science in Europe, 23: 879.

Murphy, D.J., O’ Brien, B., Hennessy, D., Hurley, M and Murphy, M.D. 2021a. Evaluation of the precision of the rising plate meter for measuring compressed sward height on heterogeneous grassland swards. Precision Agriculture 22: 922-946.

Murphy, D.J., Shine, P., O’Brien, B., O'Donovan, M. and Murphy, M.D. 2021b. Utilising grassland management and climate data for more accurate prediction of herbage mass using the rising plate meter. Precision Agriculture 22: 1189-1216.

Noci, F., Monahan, F.J., French, P. and Moloney, A.P. 2005. The fatty acid composition of muscle fat and subcutaneous adipose tissue of pasture-fed beef heifers: influence of the duration of grazing. Journal of Animal Science 83: 1167-1178.

O'Callaghan, T.F., Hennessy, D., McAuliffe, S., Kilcawley, K.N., O'Donovan, M., Dillon, P., Ross, R.P. and Stanton, C. 2016. Effect of pasture versus indoor feeding systems on raw milk composition and quality over an entire lactation. Journal of Dairy Science 99: 9424-9440.

O'Donovan, M., Dillon, P., Rath, M. and Stakelum, G. 2002. A comparison of four methods of herbage mass estimation. Irish Journal of Agricultural and Food Research 41: 17-27.

O'Donovan, M. and Delaby, L. 2005. A comparison of perennial ryegrass cultivars differing in heading date and grass ploidy with spring calving dairy cows grazed at two different stocking rates. Animal Research 54: 337-350.

O'Donovan,M., McHugh, N., McEvoy, M., Grogan, D. and Shalloo, L. 2016. Combining seasonal yield, silage dry matter yield, quality and persistency in an economic index to assist perennial ryegrass variety selection. The Journal of Agricultural Science 155: 556-568.

O'Donovan, M., Hennessy, D. and Creighton, P. 2020. Ruminant grassland production systems in Ireland. Irish Journal of Agricultural and Food Research 52. DOI: 10.15212/IJAFR-2020-0118.
Orr, R.J., Parsons, A.J., Penning, P.D. and Treacher, T.T. 1990. Sward composition, animal performance and the potential production of grass/white clover swards continuously stocked with sheep. Grass and Forage Science 45: 325-336.

Peeters, A. and Kopec, S. 1996. Production and productivity of cutting grasslands in temperature climates of Europe. Grassland Science in Europe 1: 59-73.

Pembleton, L.W., Inch, C., Baillie, R.C., Drayton, M.C., Thakur, P., Ogaji, Y.O., Spangenberg, G.C., Forster, J.W., Daetwyler, H.D. and Cogan, N.O.I. 2018. Exploitation of data from breeding programs supports rapid implementation of genomic selection for key agronomic traits in perennial ryegrass. Theoretical and Applied Genetics 131: 1891-1902.

Peyraud, J.L., Le Gall, A. and Luscher, A. 2009. Potential food production from forage legume-based-systems in Europe: an overview. Irish Journal of Agricultural and Food Research 48: 115-135.

Roche, J.R., Dillon, P., Crosse, S. and Rath, M. 1996. The effect of closing date of pasture in autumn and turnout date in spring on sward characteristics, dry matter yield and milk production of spring-calving dairy cows. Irish Journal of Agricultural and Food Research 35: 127-140.

Ruelle, E., Delaby, L. and Hennessy, D. 2018. Development of the Moorepark St Gilles grass growth model (MoSt GG model): a predictive model for grass growth for pasture based systems. European Journal of Agronomy 99: 80-91.

Stakelum, G. and Dillon, P. 2004. The effect of herbage mass and allowance on herbage intake, diet composition and ingestive behaviour of dairy cows. Irish Journal of Agricultural and Food Research 43: 17-30.

Stakelum, G. and Dillon, P. 2007. The effect of grazing pressure on rotationally grazed pastures in spring/early summer on the performance of dairy cows in the summer/autumn period. Irish Journal of Agricultural and Food Research 46: 29-46.

Stewart, A. and Hayes, R. 2011. Ryegrass breeding - balancing trait priorities. Irish Journal of Agricultural and Food Research 50: 31-46.

Teagasc. 2020. "Teagasc Sectoral Roadmaps 2027". Available online: https://www.teagasc.ie/publications/2020/teagasc-sectoralroadmaps-2027.php [Accessed 02 June 2021].

Thomas, C., Gibbs, B.G. and Tayler, J.C. 1981. Beef production for silage. 2. The performance of beef cattle given silages of either perennial ryegrass or red clover. Animal Science 32: 149-153.

Tubritt, T., Delaby, L., Gilliland, T. and O'Donovan, M. 2020. An investigation into the grazing efficiency of perennial ryegrass varieties. Grass and Forage Science 75: 253-265.

Tunon, G.E. 2013. Improving the use of perennial ryegrass swards for dairying in Ireland. PhD thesis, Massey University, Palmerston North, New Zealand.

Ulyatt, M.J. 1970. Evaluation of pasture quality under New Zealand conditions. Proceedings of the New Zealand Grassland Association 32: 61-68. 
Wilkins, P.W. and Humphreys, M.O. 2003. Progress in breeding perennial forage grasses for temperate agriculture. Journal of Agricultural Science 140: 129-150.

Wims, C.M., Deighton, M.H., Lewis, E., O’Loughlin, B., Delaby, L., Boland, T.M. and O'Donovan, M. 2010. Effect of pre-grazing herbage mass on methane production, dry matter intake and milk production of grazing dairy cows during the mid season period. Journal of Dairy Science 93: 4976-4985.
Wims, C.M., McEvoy, M., Delaby, L., Boland, T.M. and O'Donovan, M. 2013. Effect of perennial ryegrass (Lolium perenne L.) cultivars on the milk yield of grazing dairy cows. Animal 7: 410-421.

Wims, C.M., Delaby, L., Boland, T.M. and O'Donovan, M. 2014. Effect of pre-grazing herbage mass on dairy cow performance, grass dry matter production and output from perennial ryegrass (Lolium perenne L.) pastures. Animal 8: 141-151. 